\title{
Problem deficit bias a skuteczność unijnych reguł fiskalnych
}

Małgorzata Potocka*

\section{Wstęp}

Reguły fiskalne są jednym z elementów ram polityk fiskalnych. Zgodnie z definicją najczęściej występującą w literaturze, stosowaną m.in. przez Międzynarodowy Fundusz Walutowy (np. Schaechter i in. 2012, s. 5) i Komisję Europejską (2010, s. 99), reguły fiskalne to reguły nakładające w sposób długotrwały ograniczenia na politykę fiskalną za pomocą numerycznych limitów odnoszących się do tzw. agregatów budżetowych, tj.: deficytu budżetowego (w ujęciu nominalnym lub strukturalnym), długu publicznego, dochodów budżetowych lub wydatków budżetowych.

Reguły fiskalne w Europie określane są na poziomie poszczególnych krajów, ale także na poziomie UE. Celem niniejszego artykułu jest przeanalizowanie stopnia przestrzegania przez 15 krajów $U^{1}{ }^{1}$ reguł fiskalnych w latach 1999-2015 i ewolucji reguł od początku ich sformułowania, czyli także ocenienie tego, w jakim zakresie reguły fiskalne UE są skuteczne, jeśli chodzi o nakładanie ograniczeń na politykę fiskalną.

\section{Reguły fiskalne a zjawisko deficit bias}

Komisja Europejska podkreśla, że celem reguł fiskalnych jest nałożenie ograniczeń na dyskrecjonalne decyzje fiskalne rządów w celu sprzyjania „odpowiedzialnej polityce fiskalnej" (Komisja Europejska 2010, s. 99). Precyzyjniej rzecz ujmując, reguły fiskalne powinny służyć dyscyplinie finansów publicznych,

\footnotetext{
* Małgorzata Potocka - magister, Szkoła Główna Handlowa, Kolegium Gospodarki Światowej, potocka.gosia@gmail.com.

${ }_{1}^{1}$ Analiza dotyczy 15 krajów UE, które najdłużej są członkami UE.
} 
a w szczególności ograniczaniu zjawiska tzw. deficit bias, czyli tendencji do regularnego wykazywania nadwyżek wydatków państwa nad dochodami (Calmfors 2014, s. 2). W szczególności chodzi o ograniczanie bodźców decydentów w sprawach budżetu do wyrażania zgody na występowanie zjawiska (Wyplosz 2012, s. 9). Jak widać na wykresie 1, taka tendencja dominuje w krajach Unii Europejskiej (UE) co najmniej od początku lat 80 . Wykres pokazuje, że występowanie deficytów budżetowych jest trwałe. Nie zależy ono zatem od warunków gospodarczych, a od tego, w jakim momencie cyklu gospodarczego (boom, recesja) znajduje się gospodarka unijna. Brak nadwyżek budżetowych w tak długim okresie prowadzi do wniosku, że przynajmniej niektóre kraje UE nie prowadziły w analizowanym okresie antycyklicznej, czyli stabilizacyjnej, polityki fiskalnej.

Wykres 1. Deficyty/nadwyżki sektora general government (g.g.) w UE i strefie euro (jako \% PKB) w latach 1972-2014

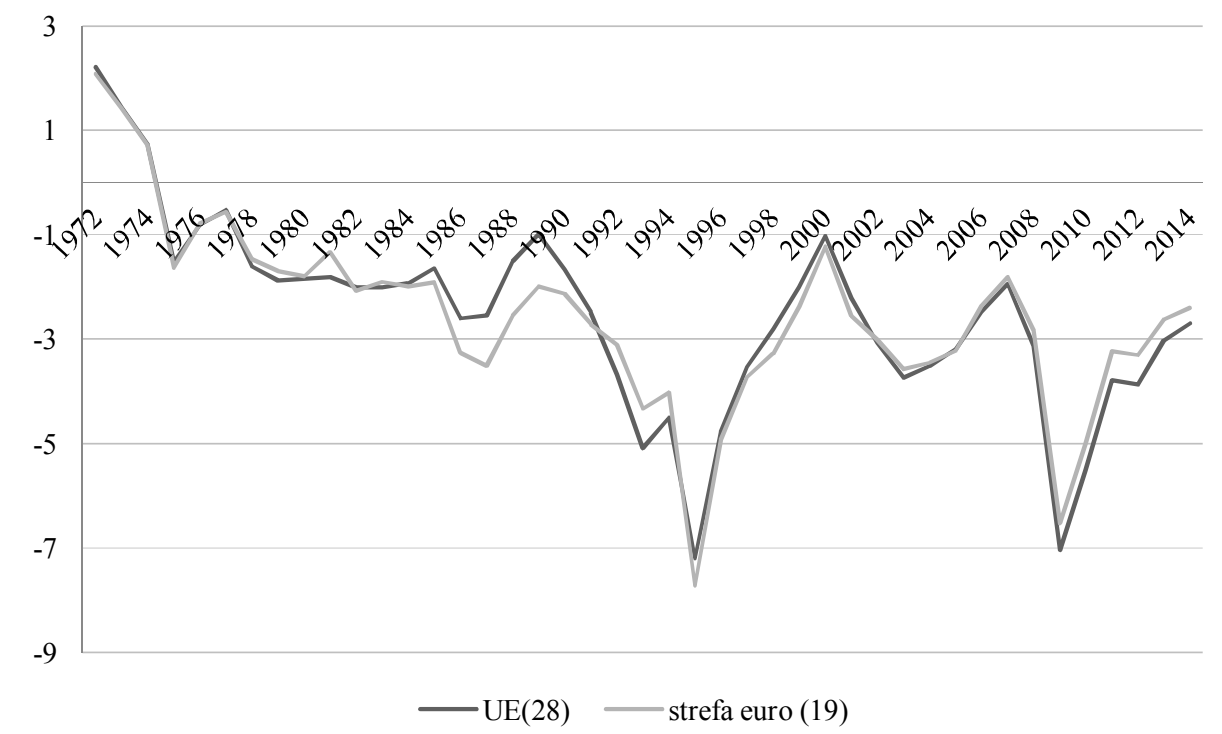

Źródło: World Data Bank.

Jeśli chodzi o występowanie zjawiska w poszczególnych krajach Unii Europejskiej (patrz wykres 2), to niektóre kraje w mniejszym, inne w większym stopniu ulegały zjawisku deficit bias. Przykładowo w Niemczech średni wynik salda budżetowego w latach 1981-2014 wyniósł -1,6\% PKB, a w Grecji: $-8,4 \%$ PKB.

Warto dodać, że zjawisko deficit bias występowało w większości krajów UE trwale, mniej więcej od początku lat 80., także przed kryzysem w strefie euro. W latach 1981-2006 średni deficyt w Niemczech wynosił 1,8\% PKB, a w Grecji $7,7 \%$ PKB. 
Wykres 2. Deficyty/nadwyżki sektora g.g. w wybranych krajach strefy euro (jako \% PKB) w latach 1972-2014

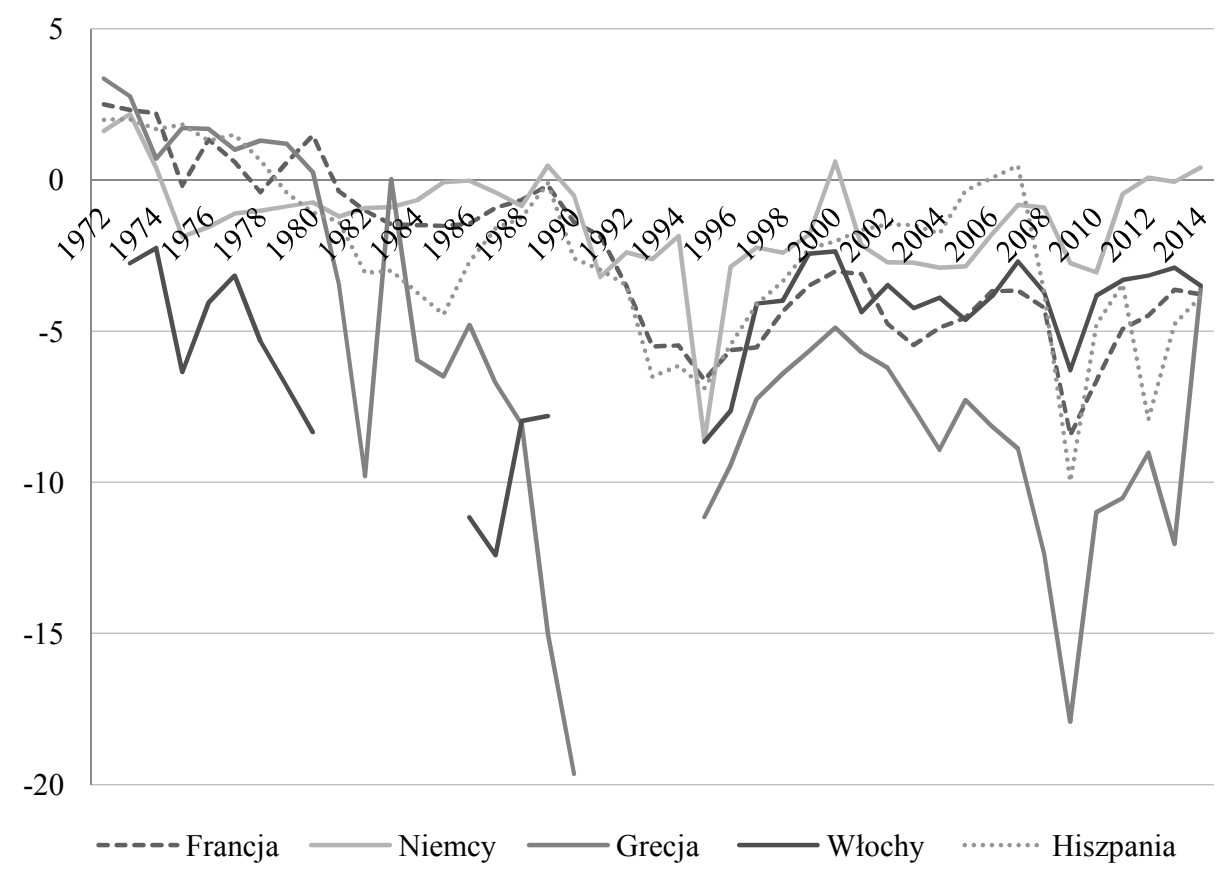

Źródło: World Data Bank.

Patrząc na powyższe wykresy, możemy sobie zadać pytanie o skuteczność reguł fiskalnych w krajach UE. Jeśli kraje nie osiągają celu, jakiemu służą reguły fiskalne, to czy występowanie zjawiska deficit bias wynika bardziej z konstrukcji tych reguł czy z ich nieprzestrzegania? Próba odpowiedzi na te pytania została podjęta w niniejszym artykule.

\section{Reguły fiskalne obowiązujące w Unii Europejskiej}

Obecnie w krajach UE występują zarówno reguły unijne, jak i krajowe, jednak przedmiotem oceny w tym artykule są jedynie reguły unijne. Na wstępie trzeba zaznaczyć, że prowadzenie polityki fiskalnej pozostaje w kompetencjach rządów poszczególnych krajów i zgodnie z Traktatem o Funkcjonowaniu Unii Europejskiej (TFUE) państwa członkowskie koordynują jedynie swoje polityki gospodarcze (w tym politykę fiskalną) w ramach Unii. Budżet samej Unii jest relatywnie mały (ok. 1\% unijnego PKB) i nie pełni funkcji stabilizacyjnej. Oznacza to, że instytucje unijne nie mają możliwości bezpośredniego wpływania na politykę fiskalną krajów członkowskich. 
Niemniej jednak, zgodnie z art. 126 ust. 1 TFUE, państwa członkowskie unikają nadmiernego deficytu budżetowego. Ten sam artykuł (ust. 2-13) odnosi się także do kolejnych kroków podejmowanych przez Komisję i Radę UE w ramach tzw. procedury nadmiernego deficytu. Zgodnie z zapisami artykułu niepodejmowanie przez dane państwo członkowskie strefy euro działań mających na celu wyeliminowanie nadmiernego deficytu (rozumianego jako przekroczenie wielkości odniesienia dla stosunku planowanego lub rzeczywistego deficytu budżetowego do PKB lub/i dla stosunku długu publicznego do PKB) może ostatecznie prowadzić do zażądania przez Radę UE złożenia nieoprocentowanego depozytu („,o stosownej wielkości”) aż do momentu skorygowania deficytu lub do nałożenia grzywny „stosownej wysokości”. Przepisy uzupełniające dotyczące stosowania procedury znajdują się w protokole (nr 12) dołączonym do traktatów. Przede wszystkim zawarto w nim wartości odniesienia dla dopuszczalnych wartości deficytu i długu w stosunku do PKB (odpowiednio 3\% i 60\%). Art. 121 ust. 3 TFUE odnosi się z kolei do koordynacji polityki gospodarczej (w tym fiskalnej) przez kraje członkowskie, dając Radzie uprawnienia do nadzorowania rozwoju sytuacji gospodarczej w każdym państwie członkowskim, zgodności polityk gospodarczych z ogólnymi kierunkami polityk gospodarczych państw i UE oraz dokonywania oceny całościowej.

Wtórnym aktem prawnym, który precyzuje i wzmacnia zapisy paktu, m.in. dotyczące przestrzegania reguł fiskalnych w UE, jest przyjęty w 1997 r. pakt stabilności i wzrostu. Pakt był dwukrotnie reformowany. Celem reformy z $2005 \mathrm{r}$. było lepsze uwzględnienie uwarunkowań gospodarczych (cyklicznych) i specyficznej sytuacji poszczególnych krajów członkowskich (Komisja Europejska 2016, s. 10). Pakt uzupełniono wtedy w szczególności m.in. o regułę opartą na średniookresowym celu budżetowym (medium term objective, MTO) oraz o specyficzny dla każdego kraju strukturalny cel budżetowy, umożliwiający wyłączenie efektów działania automatycznych stabilizatorów fiskalnych z oceny spełniania wymogów paktu. Określono także referencyjną wartość odniesienia dla wielkości dostosowania prowadzącego do osiągnięcia MTO. Wprowadzono też m.in. możliwość wydłużenia eliminacji nadmiernego deficytu przez kraj, który podjął odpowiednie działania, ale w którym wystąpiły nieprzewidziane niekorzystne zdarzenia gospodarcze mające poważne negatywne konsekwencje dla finansów publicznych.

Po raz drugi pakt został zreformowany w 2011 r. za pomocą pakietu legislacyjnego zwanego „sześciopakiem”. Celem reformy było zwiększenie z jednej strony wiarygodności paktu, a z drugiej - jego elastyczności. Było to następstwem problemów z przestrzeganiem zasad paktu zarówno przed kryzysem w strefie euro, jak i w czasie kryzysu. W niniejszym artykule pokazano wpływ tych reform na elastyczność oraz na wiarygodność i skuteczność reguł.

\footnotetext{
${ }^{2}$ W skład „sześciopaku” wchodzi pięć rozporządzeń Rady UE o numerach: 1175/2011, 177/2011, 1173/2011, 1176/2011 1174/2011 i dyrektywa nr 2011/85/UE.
} 
Zmiany wprowadzone przez „sześciopak” dotyczyły m.in. wprowadzenia reguły dotyczącej poziomu wydatków budżetowych jako uzupełnienia reguły dotyczącej poziomu kryterium salda strukturalnego (MTO). Ponadto wprowadzono możliwość uruchomienia sankcji wobec krajów strefy euro w przypadku nieprzestrzegania kryterium salda strukturalnego. Wzmocniono też przepisy dotyczące sankcji wobec krajów strefy euro w ramach procedury nadmiernego deficytu. Zwiększono również znaczenie kryterium długu publicznego w ramach procedury nadmiernego deficytu - od tej pory jego nieprzestrzeganie jest traktowane na równi z nieprzestrzeganiem kryterium deficytu.

Zmiany te pozostawiały pewien obszar dowolności interpretacyjnej, jeśli chodzi o ocenę sytuacji ekonomicznej w krajach członkowskich, dlatego też, w celu zwiększenia transparentności interpretacji reguł fiskalnych, w styczniu 2016 r. Komisja opublikowała komunikat (Komisja Europejska 2015), zawierający reguły interpretacji przez Komisję wymogów paktu stabilności i wzrostu w kontekście:

1) podejmowania przez kraj członkowski inwestycji;

2) podejmowania reform strukturalnych;

3) uwzględniania fazy cyklu koniunkturalnego, w której znajduje się dany kraj członkowski w momencie oceniania przez Komisję jego sytuacji fiskalnej.

Ściślejsze przestrzeganie zasad paktu w strefie miał także zapewnić tzw. „dwupak” (czyli dwa rozporządzenia Rady UE³), który wszedł w życie w 2013 r. Jego celem było wzmocnienie koordynacji gospodarczej w krajach strefy euro ( $w$ tym w zakresie polityki fiskalnej) i ustanowienie nowych narzędzi monitorowania i nadzoru tej polityki.

Poza zreformowanym paktem stabilności i wzrostu koordynację polityki fiskalnej, a więc i przestrzeganie reguł fiskalnych, miał wzmocnić także uzgodniony w 2012 r. przez 25 krajów członkowskich UE (poza Czechami i Wielką Brytanią) międzyrządowy traktat o stabilności, koordynacji i zarządzaniu, a zwłaszcza tzw. pakt fiskalny, stanowiący część traktatu (tytuł III), do którego przestrzegania zobowiązały się kraje strefy euro: Dania, Bułgaria i Rumunia. W pakcie fiskalnym określono m.in. wymóg dotyczący minimalnego poziomu deficytu strukturalnego w wysokości $0,5 \%$ PKB. Ponadto, zgodnie z wymogami paktu, wymóg ten miał zostać zapisany w prawodawstwie krajowym państw-sygnatariuszy traktatu „w miarę możliwości” rangi konstytucyjnej.

Podsumowując - głównym aktem prawnym, który reguluje zasady stosowania reguł fiskalnych pozostaje skonsolidowany pakt stabilności i wzrostu. Zawiera zarówno reguły fiskalne w ramach procedury nadmiernego deficytu - tzw. część korygująca, wywodząca się z art. 126 TFUE - jak i reguły fiskalne dla krajów, które nie wykazują nadmiernego deficytu, tzw. część prewencyjna, wywodząca się z art. 121 TFUE. W ramach części prewencyjnej reguły dotyczą salda struk-

\footnotetext{
${ }^{3}$ Rozporządzenia nr 472/2013 i 473/2013.
} 
turalnego i wydatków rządowych, a w ramach części korygującej reguły oparte są na wielkości długu i deficytu publicznego. Reguły i sposób ich egzekwowania, a także odstępstwa od wymogu ich przestrzegania zostały szczegółowo opisane w tabelach 1 i 2.

Tabela 1. Reguły fiskalne w UE - część prewencyjna paktu stabilności i wzrostu

Saldo strukturalne - saldo sektora instytucji rządowych i samorządowych uwzględniające zmiany cykliczne i skorygowane o działania jednorazowe i tymczasowe, tzw. średniookresowy cel budżetowy (medium term objective - MTO).

Wydatki publiczne, skorygowane o: koszt odsetek, wydatki na programy UE równoważone dochodami z unijnych środków finansowych, niedyskrecjonalne zmiany w wydatkach na zasiłki dla bezrobotnych.

MTO: określany indywidualnie przez każdy kraj członkowski, limit MTO wyznaczany przez Komisję na podstawie określonej metodologii. Dla krajów należących do strefy euro i ERMII limit MTO $=-1 \%$ PKB.

Dla państw-sygnatariuszy paktu fiskalnego limit $M T O=-0,5 \%$ PKB lub, jeśli dtug jest znacznie poniżej $60 \%$ PKB i nie ma dużych ryzyk dla stabilności finansów publicznych, $-1 \%$ PKB.

Możliwe odstępstwa od MTO:

- gdy odstępstwo związane jest z wdrażaniem znaczących reform strukturalnych, które bezpośrednio pociągają za sobą poprawę finansów publicznych w długim okresie, w tym trwale zwiększając wzrost potencjalny, a w związku z tym reform mających możliwy do zweryfikowania wpływ na długookresową stabilność finansów publicznych;

- jeżeli odstępstwo wynika z nadzwyczajnego i niezależnego od danego państwa członkowskiego zdarzenia, które wywiera istotny wpływ na saldo sektora instytucji rządowych i samorządowych;

- $\quad$ w przypadku poważnego pogorszenia koniunktury gospodarczej w strefie euro lub całej Unii, o ile nie zagraża to stabilności finansów publicznych w średnim okresie.

Wydatki publiczne: w przypadku kraju, w którym saldo strukturalne $=$ MTO, roczne tempo wzrostu wydatków publicznych nie powinno przekraczać średniookresowego tempa wzrostu potencjalnego PKB.

W przypadku nieosiągnięcia MTO kraje powinny zmierzać do niego w tempie 0,5 p. proc. PKB rocznie.

Możliwe odstępstwa od ścieżki dostosowawczej:

- gdy odstępstwo związane jest z wdrażaniem znaczących reform strukturalnych, które bezpośrednio pociągają za sobą poprawę finansów publicznych $\mathrm{w}$ długim okresie, $\mathrm{w}$ tym trwale zwiększając wzrost potencjalny, a w związku z tym reform mających możliwy do zweryfikowania wpływ na długookresową stabilność finansów publicznych;

- jeżeli odstępstwo wynika z nadzwyczajnego i niezależnego od danego państwa członkowskiego zdarzenia, które wywiera istotny wpływ na saldo sektora instytucji rządowych i samorządowych;

- $\quad$ w przypadku poważnego pogorszenia koniunktury gospodarczej w strefie euro lub całej Unii, o ile nie zagraża to stabilności finansów publicznych w średnim okresie.

Wydatki publiczne:

Dopóki średniookresowy cel budżetowy nie zostanie osiągnięty (saldo strukturalne < MTO), roczne tempo wzrostu wydatków publicznych nie powinno być niższe niż średniookresowe tempo wzrostu potencjalnego PKB. Tempo to jest określone tak, aby zapewnić odpowiednie dostosowanie w celu osiągnięcia MTO przez saldo strukturalne.

Ponadto jakiejkolwiek zmianie pozycji przychodów muszą towarzyszyć analogiczne zmiany po stronie wydatków i/lub uznaniowe zmiany innych pozycji przychodów. 
Procedura korygowania „znaczącego odchylenia” od MTO oznacza, że:

- podczas oceny zmiany salda strukturalnego odstępstwo od MTO lub ścieżki dostosowawczej wynosi co najmniej 0,5 p. proc. PKB w ciągu jednego roku lub co najmniej 0,25 p. proc. PKB średnio rocznie w ciągu dwóch kolejnych lat;

- podczas oceny tempa wzrostu wydatków skorygowanego o skutki działań dyskrecjonalnych po stronie dochodów odstępstwo ma łączny wpływ na saldo sektora instytucji rządowych i samorządowych w wysokości co najmniej 0,5 p. proc PKB w ciągu jednego roku lub narastająco w ciągu dwóch kolejnych lat.

Wobec krajów strefy euro możliwe jest zastosowanie sankcji w przypadku stałego niewypełniania wymogów paktu - oprocentowany depozyt w wysokości $0,2 \%$ PKB.

Źródło: opracowanie własne.

Tabela 2. Reguły fiskalne w UE - część korygująca paktu stabilności i wzrostu

\begin{tabular}{|c|c|}
\hline Wskaźniki & $\begin{array}{l}\text { Saldo nominalne sektora instytucji rządowych i samorządowych. } \\
\text { Dług publiczny. }\end{array}$ \\
\hline Kryterium & $\begin{array}{l}\text { Saldo budżetowe: limit w wysokości } 3 \% \text { PKB. } \\
\text { Możliwe odstępstwa od limitu deficytu: } \\
\text { - } \quad \text { deficyt zmniejsza się znacząco i stale i osiąga poziom bliski 3\%; } \\
\text { przekroczenie wartości referencyjnej ma charakter wyjątkowy (wynika } \\
\text { z nadzwyczajnego i niezależnego od państwa zdarzenia lub z poważnego } \\
\text { pogorszenia koniunktury) oraz tymczasowy i wskaźnik ten pozostaje zbli- } \\
\text { żony do wartości referencyjnej; } \\
\text { - w przypadku krajów, których dług publiczny nie przekroczył } 60 \% \text { PKB, } \\
\text { uwzględniana jest rola ,innych istotnych czynników” związanych ze: } \\
\text { średniookresową sytuacją gospodarczą, średniookresową sytuacją budże- } \\
\text { tową, zmianami długu publicznego oraz innych dodatkowych czynników, } \\
\text { które w opinii zainteresowanego państwa członkowskiego są istotne dla } \\
\text { kompleksowej oceny spełniania kryterium; } \\
\text { w krajach, których dług nie przekroczył } 60 \% \text { PKB, a odstępstwo deficytu } \\
\text { od poziomu } 3 \% \text { nie jest znaczące, kryterium jest uznane za spełnione, je- } \\
\text { śli przeprowadzają one reformę systemu emerytalnego przyczyniającą się } \\
\text { ona do długoterminowej stabilności finansów publicznych i stwarzającą } \\
\text { zagrożenie dla średnioterminowej sytuacji budżetowej. } \\
\text { Dług publiczny: limit w wysokości } 60 \% \text { PKB lub zmniejszający się dostatecz- } \\
\text { nie i zbliżający do wartości odniesienia - warunek spełniony, jeśli różnica po- } \\
\text { między wielkością długu w stosunku do PKB a wielkością odniesienia zmniej- } \\
\text { sza się w średnim rocznym tempie } 0,05 \% \text { tej różnicy przez trzy lata. } \\
\text { Możliwe odstępstwa od limitu długu: } \\
\text { - } \\
\text { w odniesieniu do krajów objętych procedura nadmiernego deficytu } \\
\text { w dniu przyjęcia „,sześciopaku” (8 listopada } 2011 \text { r.) przez trzy lata od } \\
\text { korekty nadmiernego deficytu kryterium uznaje się za spełnione, jeśli } \\
\text { dane państwo osiągnie „wystarczający postęp” w jego przestrzeganiu } \\
\text { (określony w vademecum paktu); } \\
\text { uwzględniana jest rola ,innych istotnych czynników”, związanych ze } \\
\text { średniookresowa sytuacją gospodarczą, średniookresową sytuacją budże- } \\
\text { towá, zmianami długu publicznego, oraz innych dodatkowych czynników, } \\
\text { które w opinii zainteresowanego państwa członkowskiego są istotne dla } \\
\text { kompleksowej oceny spełniania kryterium. }\end{array}$ \\
\hline
\end{tabular}




\begin{tabular}{|l|l|}
\hline $\begin{array}{l}\text { Ścieżka do- } \\
\text { stosowawcza }\end{array}$ & $\begin{array}{l}\text { Minimalne roczne dostosowanie salda strukturalnego w wysokości co najmniej } \\
\text { 0,5 proc. pKB. Możliwe wydłużenie czasu dostosowania w przypadku nie- } \\
\text { przewidzianych niekorzystnych zdarzeń gospodarczych lub w okresach znacz- } \\
\text { nego pogorszenia koniunktury w strefie euro lub UE. }\end{array}$ \\
\hline Egzekwowanie & $\begin{array}{l}\text { Możliwość ograniczenia części lub całości środków na zobowiajzania z euro- } \\
\text { pejskich funduszy strukturalnych i inwestycyjnych. Wobec krajów strefy euro } \\
\text { możliwe sankje na różnych etapach procedury nadmiernego deficytu. }\end{array}$ \\
\hline
\end{tabular}

Źródło: opracowanie własne.

\section{Ocena skuteczności poszczególnych reguł fiskalnych UE i trudności z nią związane}

W niniejszym artykule próba oceny skuteczności paktu skupia się przede wszystkim na ocenie spełniania kryteriów określonych regułami paktu stabilności i wzrostu (wskazanych w drugim wierszu tabel 1 i 2). Analiza dotyczy lat 19992016 (w miarę dostępności danych) i 15 krajów UE (UE 15), które przez cały ten okres były członkami ugrupowania, w tym 12 krajów, które od momentu powstania UGW były jej członkami.

\section{Nominalne saldo budżetowe i dług publiczny}

Analiza wypełniania limitów określonych w pakcie przeprowadzona jest na podstawie danych zaprezentowanych na wykresach 3-6.

Stopień spełniania wymogu dotyczącego limitu 3\% PKB przez deficyty krajów UE15 w badanym okresie przedstawia wykres 3. Średnio kraje te wypełniały limit deficytu przez 10, 4 lata (61\% czasu trwania okresu 1999-2015). Krajem, który ani razu nie spełnił wymaganego limitu, była Grecja, natomiast Szwecji i Luksemburgowi udało się wypełnić kryterium deficytu przez cały analizowany okres. Gdy z analizy wyłączy się lata pokryzysowe, jej wyniki są lepsze. Średni okres wypełniania kryterium przez analizowane kraje w latach 1999-2007 wynosi 6,3 lata (70\% badanego okresu). Aż 8 krajów wypełniało limit deficytu przez wszystkie 9 lat. 
Wykres 3. Odsetek lat, w których deficyt sektora g.g. w krajach członkowskich UE15 nie był większy niż 3\% PKB (\%) w okresach a) 1999-2007 b) 1999-2015*

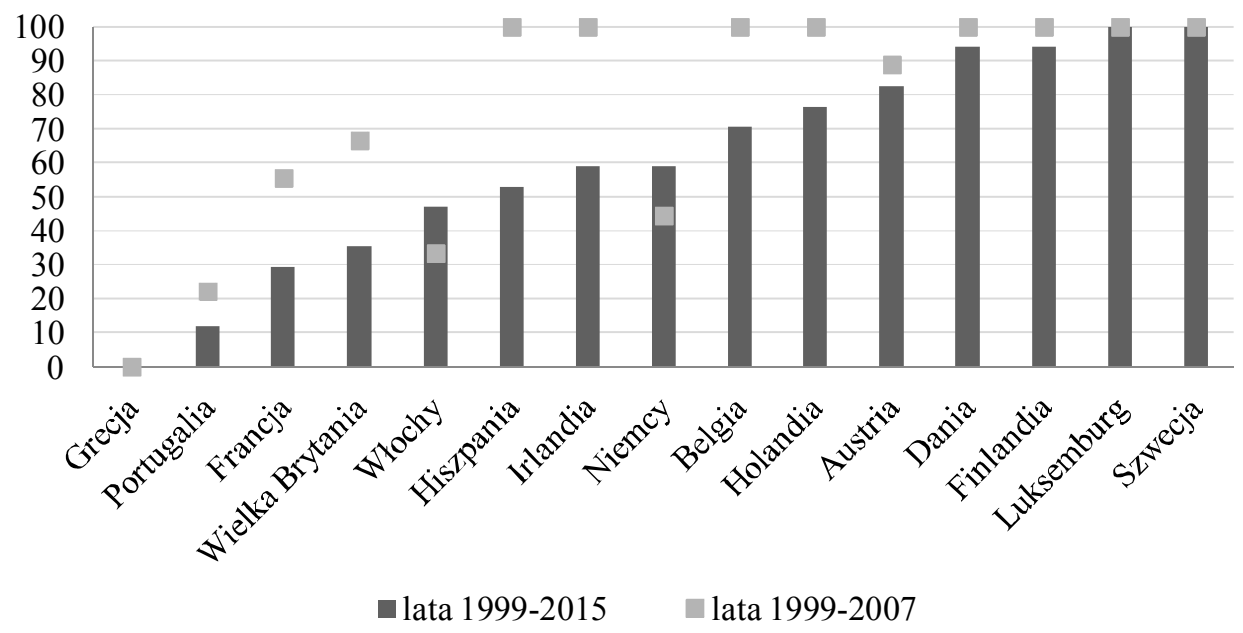

Źródło: Eurostat.

Wykres 4 potwierdza, że w latach pokryzysowych spełnianie wymogu dotyczącego limitu 3\% PKB dla deficytu nominalnego było rzadkością w krajach UE 15 i tylko 2 razy udało się to ponad połowie analizowanych krajów.

Wykres 4. Liczba krajów z UE 15, w których deficyt sektora g.g. w krajach członkowskich UE15 nie był większy niż 3\% PKB w okresie 1999-2015

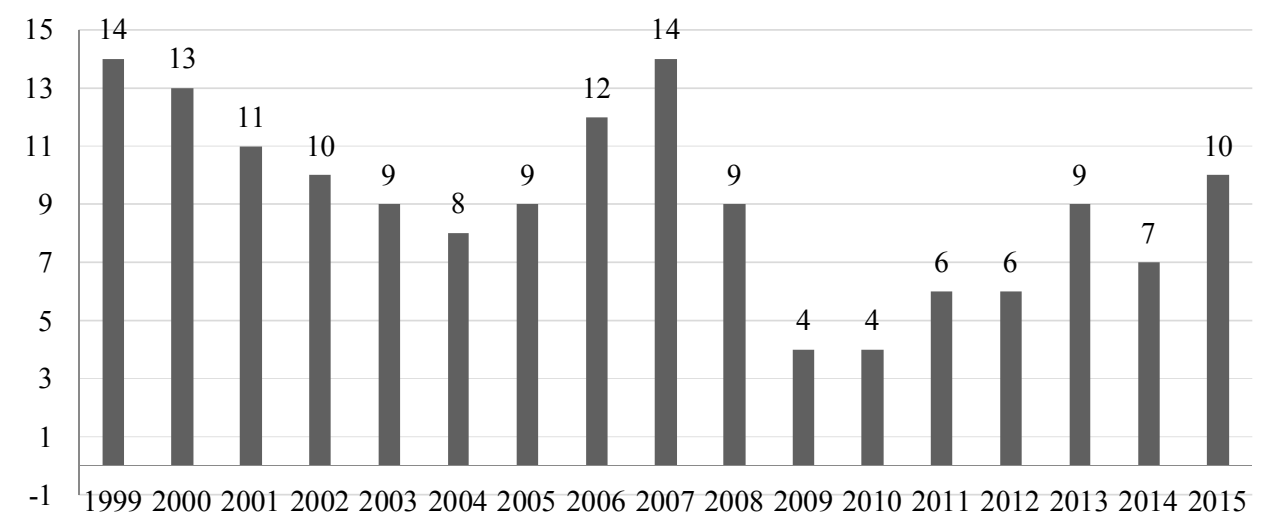

Źródło: Eurostat.

Jeśli chodzi o kryterium długu publicznego, to w czterech krajach (Austrii, Belgii, Grecji i Włoszech) przez cały okres 1999-2015 dług był wyższy niż 60\% PKB (patrz wykres 5). Jednocześnie w trzech krajach dług publiczny nie prze- 
kroczył 60\% PKB przez cały analizowany okres (Dania, Luksemburg, Szwecja). Średnia wypełniania limitu przez analizowane kraje w tych latach wynosi niemal 8 lat (47\% badanego okresu). Po wyłączeniu z oceny lat kryzysu i lat pokryzysowych (czyli lat 1999-2007) liczba krajów spełniających kryterium długu publicznego przez wszystkie 9 lat to 6 . Średnia spełniania kryterium przez analizowane kraje w tych latach jest znacznie większa i wynosi 5,5 lat (61\% badanego okresu).

Wykres 5. Odsetek lat, w których dług publiczny w krajach członkowskich UE 15 nie był większy niż 60\% PKB (\%) w okresach a) 1999-2007 b) 1999-2015*

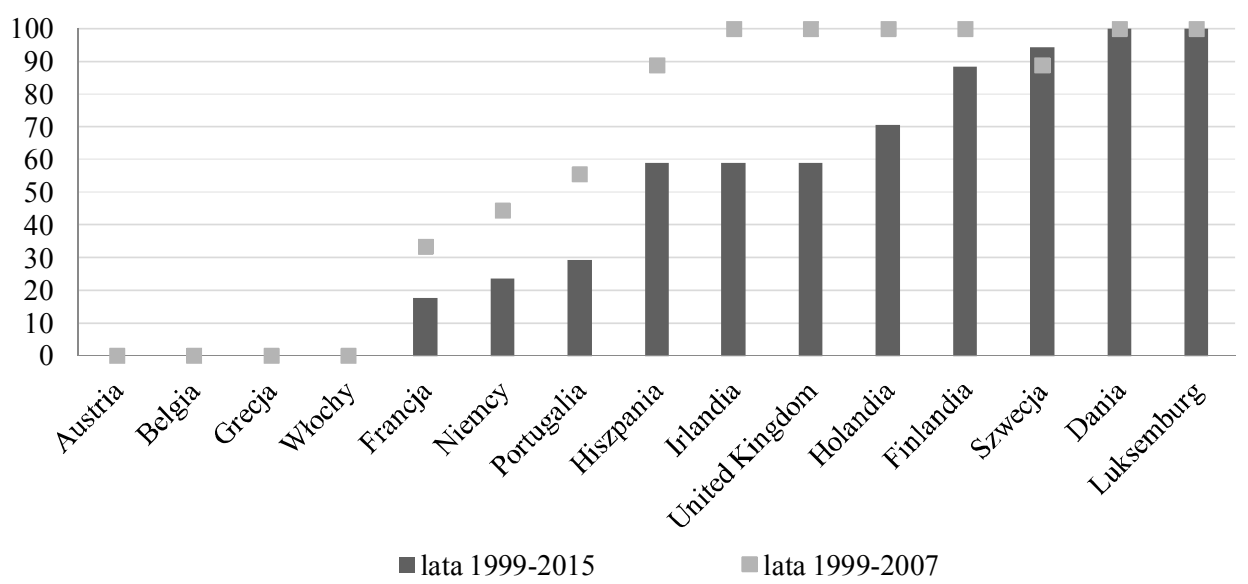

*Dane dot. Danii nie uwzględniają roku 1999.

Źródło: Eurostat.

Aby być bliższym oceny, jaką przeprowadza Komisja w stosunku do kryterium długu, można uwzględnić przypadki spełnienia kryterium także wtedy, gdy dług był większy niż $60 \%$ PKB, ale jego poziom zmniejszał się średnio w rocznym tempie równym $0,05 \%$ różnicy między aktualnym poziomem zadłużenia a wielkością referencyjną. Należy podkreślić, że przed wejściem w życie „sześciopaku” kryterium to nie było zoperacjonalizowane - pakt przewidywał jedynie, że dług będzie malał w „wystarczającym stopniu”. W artykule przyjmujemy jednak interpretację z „sześciopaku” dla całego okresu 1999-2005. Zmienia to nieco wnioski dotyczące wypełniania kryterium, szczególnie w odniesieniu do Belgii (patrz wykres 6), której poziom długu w stosunku do PKB przez cały okres znacznie przekraczał poziom $60 \%$, jednak malał przez jego połowę. Jedynie Grecja nie spełniła kryterium przez cały analizowany okres. Średni okres spełniania tak zdefiniowanego kryterium przez analizowane kraje w tych latach wynosi 9 lat (53\% badanego okresu). Lepiej wygląda sytuacja, jeśli chodzi o stopień spełniania kryterium w analizowanym okresie, gdy z okresu oceny wyłączy się lata pokryzysowe - średni okres spełniania kryterium w latach 1999-2007 wynosi 6,6 lat (73\% tego okresu). 
Wykres 6. Odsetek lat, w których dług publiczny w krajach członkowskich UE nie był większy niż $60 \%$ PKB (\%) lub jego tempo spadku zbliżało się dostatecznie do wartości odniesienia w okresach a) $1999-2007$ b) $1999-2015^{*}$

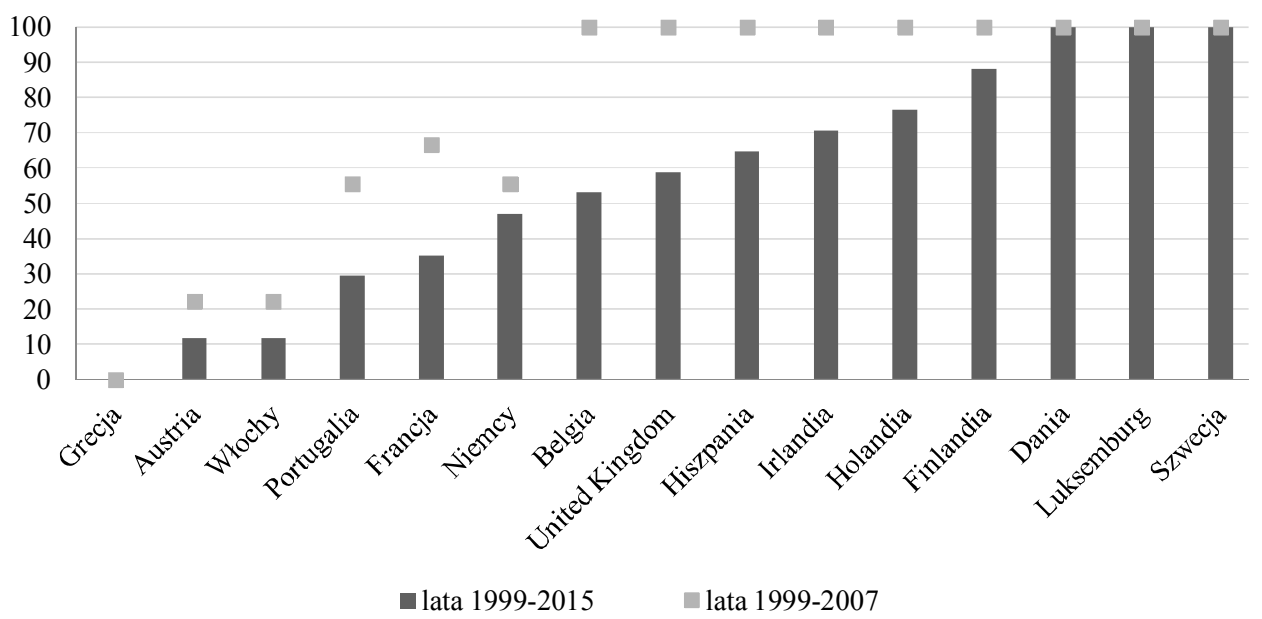

* Dane dot. Danii nie uwzględniają roku 1999.

Źródło: Eurostat.

W przypadku tak zdefiniowanego kryterium długu liczba krajów, które je spełniały (patrz wykres 7), spadała sukcesywnie od 2007 r. i dopiero od 2013 r. zaczęła rosnąć. Od 2008 r. jednak mniej niż połowa krajów UE 15 spełniała kryterium.

Wykres 7. Liczba krajów z UE15, w których dług publiczny w krajach członkowskich UE nie był większy niż 60\% PKB (\%) lub jego tempo spadku zbliżało się dostatecznie do wartości odniesienia w okresie 1999-2015

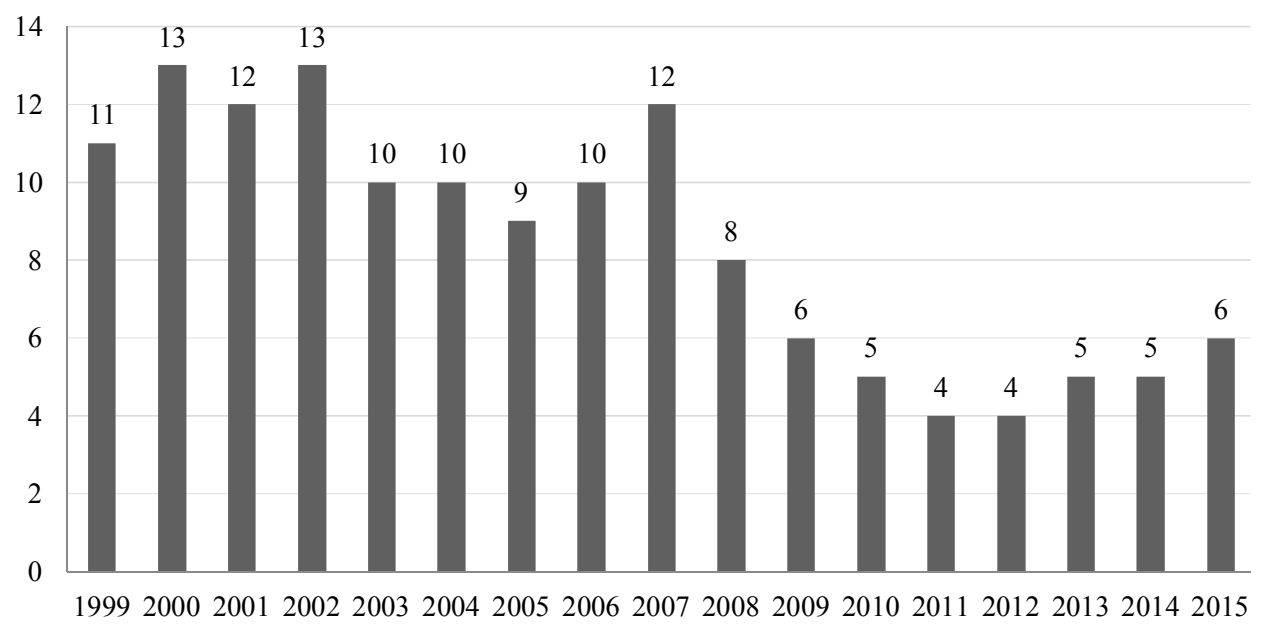

Źródło: Eurostat. 
Na koniec analizy kryteriów dhugu publicznego i deficytu warto się zastanowić, jaki jest związek pomiędzy niespełnianiem jednego z kryteriów a uruchamianiem procedury nadmiernego deficytu $\mathrm{w}$ analizowanych krajach przez Komisję (procedura jest uruchamiana, gdy Komisja uzna, że przynajmniej jedno kryterium nie zostało spełnione).

Wykres 8. Liczba krajów UE 15 niespełniających jednego z limitów długu publicznego lub deficytu (lub w których tempo spadku poziomu długu zbliżało się dostatecznie do wartości odniesienia) w okresie 1999-2015

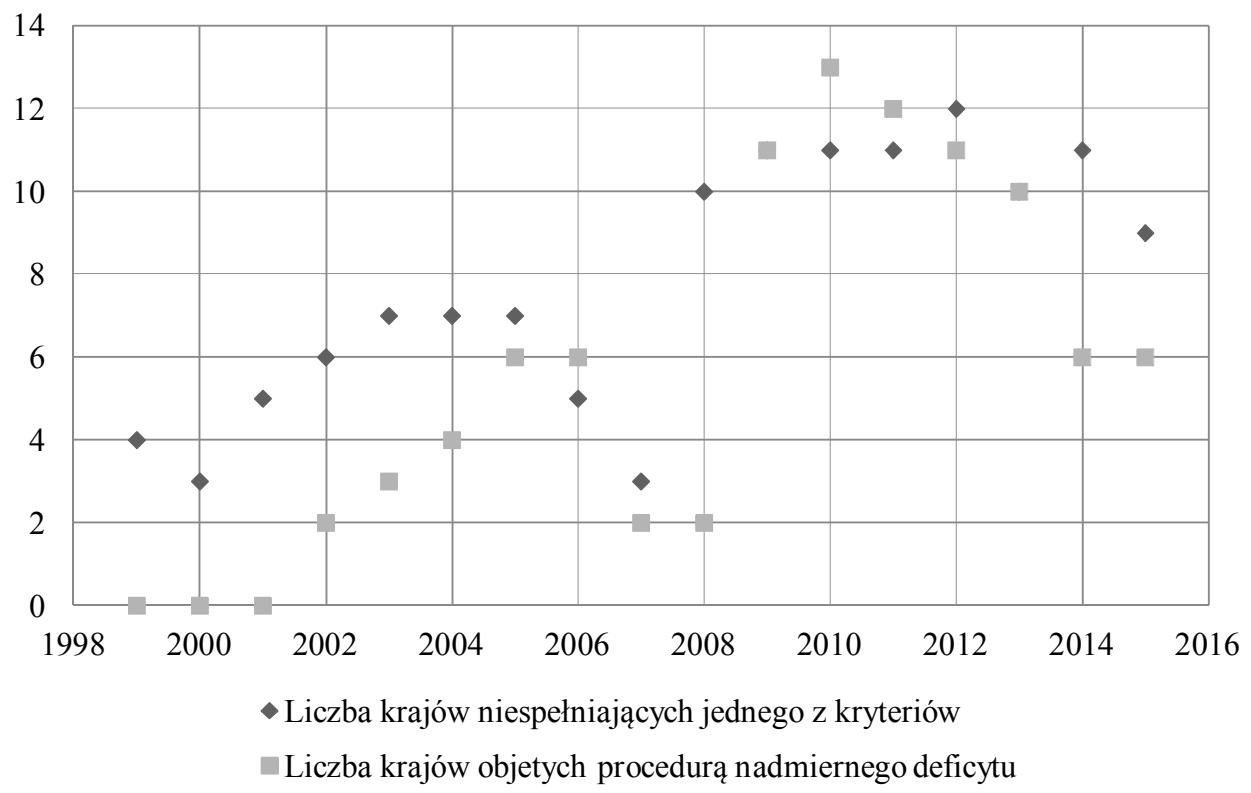

Źródło: Eurostat.

Na podstawie wykresu 8 można potwierdzić, że zachodzi związek między niespełnianiem przez kraje UE 15 jednego z limitów - długu lub deficytu publicznego - a objęciem danego kraju procedurą nadmiernego deficytu. Wykres pokazuje też, że Komisja częściej wydawała swoje rekomendacje w ramach procedury z pewnym opóźnieniem w stosunku do przekroczenia przez kraje tych limitów (tak było zwłaszcza w latach 2000-2005). Jednocześnie wykres jest dowodem na znaczne pogorszenie stopnia spełniania kryteriów paktu przez kraje członkowskie po wybuchu kryzysu. Od 2008 r. do 2015 r. co najmniej 9 z 15 krajów nie spełnia jednego z limitów określonego przez kryteria paktu (przed 2008 r. ich maksymalna liczba wynosiła 7). Choć ich liczba spada od 2012 r., to jeszcze szybciej spada liczba krajów objętych procedurą nadmiernego deficytu. Związane jest to prawdopodobnie ze zwiększoną elastycznością paktu. 


\section{Strukturalne saldo budżetowe i wydatki rządowe}

Kolejnym elementem oceny dyscypliny budżetowej krajów członkowskich, zgodnie z paktem stabilności i wzrostu, jest limit salda strukturalnego, tzn. salda nominalnego sektora g.g. po uwzględnieniu zmian cyklicznych i skorygowanego o zdarzenia jednorazowe i tymczasowe, czyli MTO. Trudności z porównywaniem spełniania tego kryterium przez poszczególne kraje i z oceną spełniania go przez dany kraj w poszczególnych latach oraz wątpliwości dotyczące oceny wynikają:

1) Ze zróżnicowanego poziomu MTO dla poszczególnych krajów członkowskich. Komisja wyznacza minimalny poziom MTO raz na 3 lata (dla krajów ze strefy euro i krajów pozostających w mechanizmie ERM2 jest to minimum $-1 \% \mathrm{PKB}^{4}$ ), a następnie kraj określa swoje MTO w programie stabilności lub konwergencji (może być on bardziej ambitny niż propozycja Komisji) ${ }^{5}$.

2) Z trudności z szacowaniem przez Komisję wysokości salda strukturalnego. Podstawą obliczenia salda strukturalnego jest wysokość salda skorygowanego o wahania cykliczne (cyclically-adjusted balance, CAB), czyli salda nominalnego skorygowanego o tzw. komponent cykliczny ${ }^{6}$. Komponent cykliczny wyliczany jest ze wzoru $\varepsilon^{*} \mathrm{OG}$, gdzie OG oznacza oszacowaną wielkość luki popytowej (output gap), czyli różnicy między produkcją realna a potencjalną, $\varepsilon$ to parametr elastyczności określający wielkość procentowej zmiany salda w stosunku do PKB w reakcji na zmiany luki popytowej. Parametr $\varepsilon$ jest określony dla salda każdego kraju członkowskiego i podlega rewizji co kilka lat ${ }^{7}$. Szacunki OG są obarczone niepewnością i podlegają znaczącym i częstym uaktualnieniom, co widać w każdych kolejnych edycjach prognoz gospodarczych Komisji. W praktyce bieżący OG jest trudny do oszacowania, szczególnie w momentach zwrotnych cyklu gospodarczego lub w przypadku zmian strukturalnych gospodarek (np. Mourre i in. 2014, s. 9). W rezultacie oszacowana przez kraje w roku n-1 wartość salda strukturalnego na bieżący (n-1) i kolejny (n) rok, która ma być porównywana z docelowym poziomem MTO, różni się od salda strukturalnego oszacowanego w roku n dla roku n-1 i roku n. Co więcej, wyniki tych szacunków zmieniają się w kolejnych

\footnotetext{
${ }^{4}$ Sygnatariusze paktu fiskalnego zobowiązali się do wyznaczania MTO na poziomie co najmniej $-0,5 \%$ PKB, ale zasady paktu odnoszą się do poziomu $-1 \%$ PKB.

${ }^{5} \mathrm{Na}$ marginesie warto dodać, że Wielka Brytania nie wyznacza MTO. Jest to zgodne z protokołem 15 TFUE (w sprawie niektórych postanowień dotyczących Zjednoczonego Królestwa Wielkiej Brytanii i Irlandii Północnej), a także z art. 8 dyrektywy w sprawie wymogów dla ram budżetowych państw członkowskich (2011/85), zgodnie z którym zapisy dyrektywy dotyczące numerycznych reguł fiskalnych nie mają zastosowania do Wielkiej Brytanii.

${ }^{6}$ Saldo strukturalne jest obliczane jako CAB skorygowane o działania jednorazowe i tymczasowe. ${ }^{7}$ Zgodnie z vademecum paktu stabilności i wzrostu (Komisja Europejska 2016, s. 28), przeglądom będą podlegać wielkości, na których opierają się parametry elastyczności dla salda budżetowego, tj. parametry elastyczności dla przychodów i wydatków budżetowych (co 9 lat) i wagi poszczególnych komponentów przychodów i wydatków (co 6 lat).
} 
latach. Przykładowo: zgodnie z ostatnimi prognozami Komisji (jesień 2016 r.) saldo strukturalne Polski w 2012 r. wynosiło -3,9\% PKB. Tymczasem w momencie oceny ex ante, czyli w 2012 r., Komisja szacowała (prognozy wiosenne), że saldo wyniesie $-2,7 \%$ PKB. W roku 2013 r. (ocena ex post, prognozy wiosenne) saldo na rok 2012 zostało oszacowane na poziomie $-3,8 \%$ PKB. Dlatego też sama Komisja w przypadku oceny ex post traktuje saldo strukturalne jako zgodne z poziomem MTO, gdy wielkość odchylenia salda od MTO nie jest większa niż o 0,25 p. proc. PKB. Generalnie rewizja szacunku salda strukturalnego przez Komisję na dany rok w kolejnym roku w krajach UE przekracza średnio wymagane dostosowanie salda strukturalnego (Darvas 2016). Podważa to mocno wiarygodność reguły opartej na tym wskaźniku (patrz też Steinhouser 2016).

Warto dodać, że są różnice w szacunkach poziomu salda strukturalnego Komisji i innych instytucji - MFW, OECD, EBC (patrz tabela 3). Można mieć zatem wątpliwości co do tego, czy szacunki Komisji są wiarygodne.

Tabela 3. Szacunki salda strukturalnego w strefie euro w latach 2011-2017, wybrane instytucje

\begin{tabular}{|l|l|c|c|c|c|c|c|c|}
\hline Instytucja & Publikacja & 2011 & 2012 & 2013 & 2014 & 2015 & $2016^{*}$ & $2017^{*}$ \\
\hline $\begin{array}{l}\text { Komisja } \\
\text { Europejska }\end{array}$ & $\begin{array}{l}\text { European Eco- } \\
\text { nomic Forecast } \\
\text {-Spring 2016 }\end{array}$ & $-3,6$ & $-2,1$ & $-1,4$ & -1 & -1 & $-1,3$ & $-1,4$ \\
\hline $\begin{array}{l}\text { Międzyn. Fun- } \\
\text { dusz Walutowy }\end{array}$ & $\begin{array}{l}\text { World Economic } \\
\text { Outlook (czerwiec } \\
\text { 2016 r.) }\end{array}$ & $-3,7$ & -2 & $-1,2$ & -1 & $-0,9$ & $-1,1$ & $-0,9$ \\
\hline $\begin{array}{l}\text { Organizacja } \\
\text { Współpracy } \\
\text { Gospodarczej } \\
\text { i Rozwoju }\end{array}$ & $\begin{array}{l}\text { Economic Outlook } \\
\text { (czerwiec 2016 r.) }\end{array}$ & $-3,5$ & $-1,8$ & -1 & $-0,8$ & $-0,8$ & -1 & -1 \\
\hline $\begin{array}{l}\text { Europejski Bank } \\
\text { Centralny }\end{array}$ & $\begin{array}{l}\text { Economic Bulletin } \\
\text { (marzec 2016 r.) }\end{array}$ & - & - & $-2,2$ & $-1,8$ & $-1,7$ & $-2,1$ & $-2,2$ \\
\hline
\end{tabular}

*Prognoza.

Źródło: Parlament Europejski 2016, s. 2.

Mając na uwadze te zastrzeżenia, można jednak poglądowo sprawdzić, w jakim stopniu, w ocenie Komisji, państwa członkowskie utrzymywały poziom salda strukturalnego zgodny z MTO (patrz wykres 9). Ocena dotyczy lat 2010-2016, wynika to $z$ dostępności danych dotyczących szacunków salda strukturalnego ${ }^{8}$. Zgodnie z wykresem dotyczącym dziewięciu z 14 analizowanych krajów (Wielka Brytania jest wyłączona $\mathrm{z}$ wyznaczania MTO) nie został on spełniony w żadnym roku. Poziom salda strukturalnego równy MTO przez relatywnie najdłuższy okres utrzymywał Luksemburg.

\footnotetext{
${ }^{8}$ Ocena opiera się na szacunkach salda strukturalnego $\mathrm{z}$ wiosennych prognoz gospodarczych Komisji na $2016 \mathrm{r}$.
} 
Wykres 9. Odsetek lat, w których saldo strukturalne w krajach członkowskich UE 15 było zgodne z poziomem ich MTO (lata 2010-2016)*

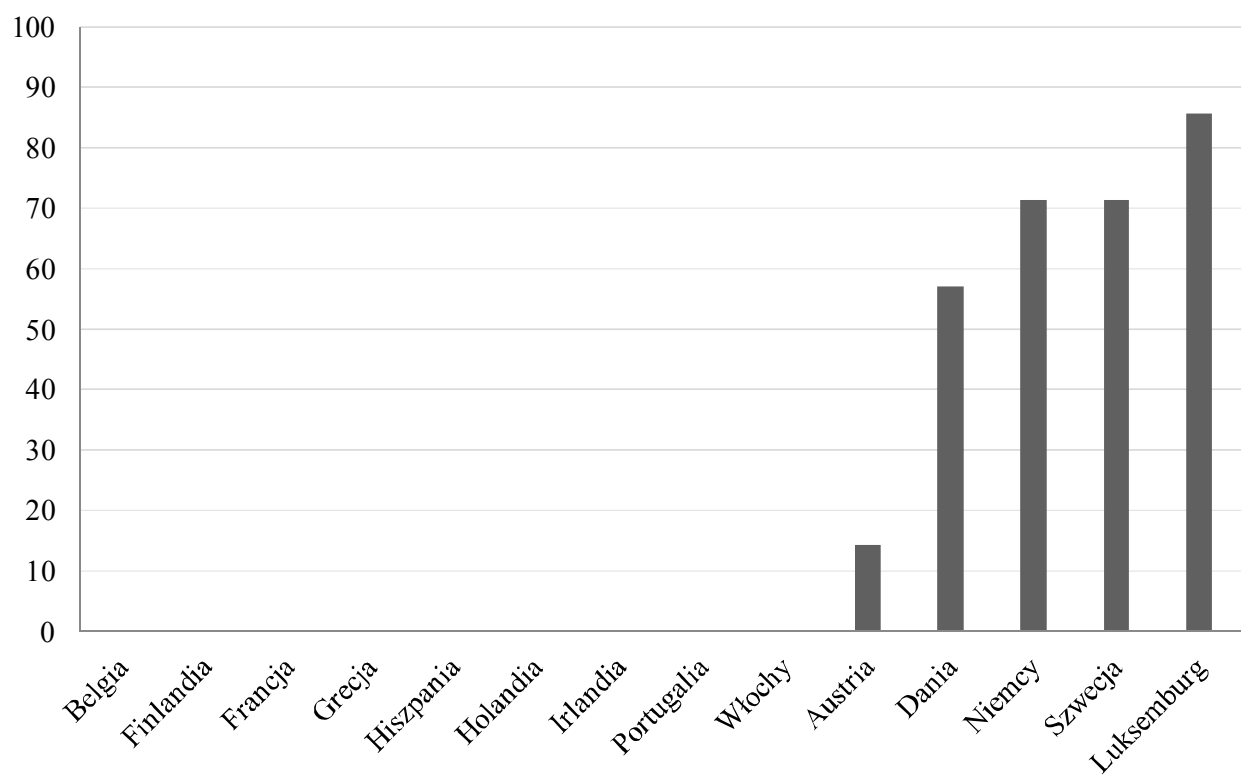

*Szacunek salda strukturalnego - zgodnie z wiosennymi prognozami Komisji z 2016 r. Wykres nie uwzględnia Wielkiej Brytanii, która jest zwolniona z wyznaczania MTO. Rok 2016, prognoza.

Źródło: AMECO.

Wykres 10 pokazuje, że od 2012 r. poziom MTO osiągały jedynie trzy z 15 analizowanych krajów.

Wykres 10. Liczba krajów UE 15, w których saldo strukturalne było zgodne z poziomem ich MTO (lata 2010-2016)*

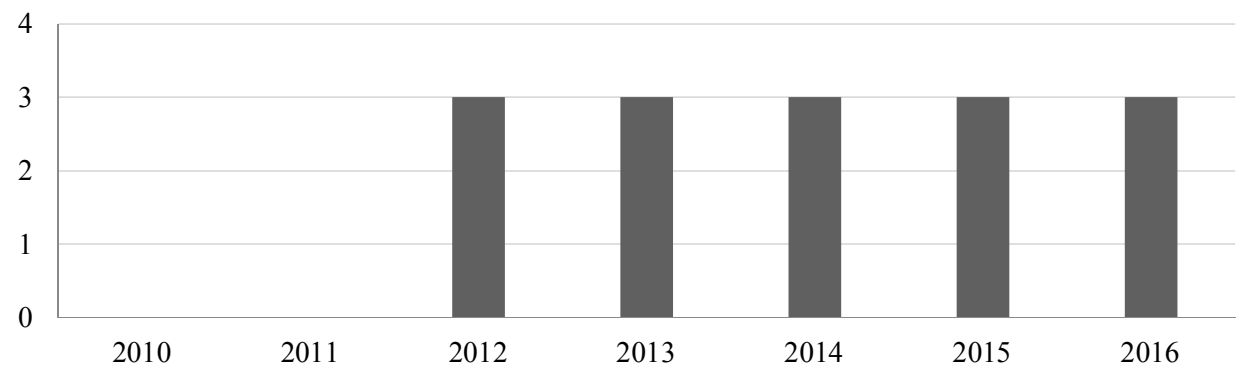

*Szacunek salda strukturalnego - zgodnie z wiosennymi prognozami Komisji z 2016 r. Wykres nie uwzględnia Wielkiej Brytanii, która jest zwolniona z wyznaczania MTO. Rok 2016, prognoza.

Źródło: AMECO. 
Aby sprawdzić, czy kraje znajdowały się na ścieżce dostosowawczej do swojego MTO w ostatnich latach (2011-2016), przeanalizowano to, jak zmieniała się liczba krajów, które osiągnęły swoje MTO lub w których saldo strukturalne zwiększało się $\mathrm{w}$ poszczególnych latach o: co najmniej 0,25 p. proc. - w przypadku krajów, w których dług publiczny przekracza lub wynosi $60 \%$ PKB; saldo było stałe lub rosło - w przypadku krajów, w których dług był niższy niż $60 \%$ PKB.

Taka skala dostosowania jest zgodna $\mathrm{z}$ minimalnym wymaganym dostosowaniem, zgodnie z komunikatem Komisji pt. Making the best use of the flexibility within the existing rules of the Stability and Growth Pact. Dotyczy dostosowania wymaganego w „wyjątkowo złych czasach” (zdefiniowanych jako czasy, w których realny wzrost PKB jest ujemny lub w których wartość luki popytowej jest niższa niż -4). Dla uproszczenia taką skalę dopasowania przyjęto dla wszystkich analizowanych krajów jako skalę minimalną.

Stopień spełniania tak zdefiniowanych kryteriów przedstawiono na wykresach 11 i 12. Widać na nim, że po 2013 r. stopień zgodności z MTO lub zdefiniowaną na minimalnym poziomie ścieżką dostosowawczą do osiągnięcia MTO znacznie się obniżył. Trzy kraje (Belgia, Finlandia, Włochy) nie spełniały tak zdefiniowanego kryterium nawet przez połowę analizowanego okresu.

Wykres 11. Liczba krajów UE 15, w których saldo strukturalne było zgodne z poziomem ich MTO lub których saldo strukturalne rosło $\mathrm{w}$ tempie 0,25 p. proc. przy zadłużeniu $>=60 \%$ PKB lub było na stałym poziomie przy zadłużeniu $>60 \%$ PKB (lata 2011-2016)*

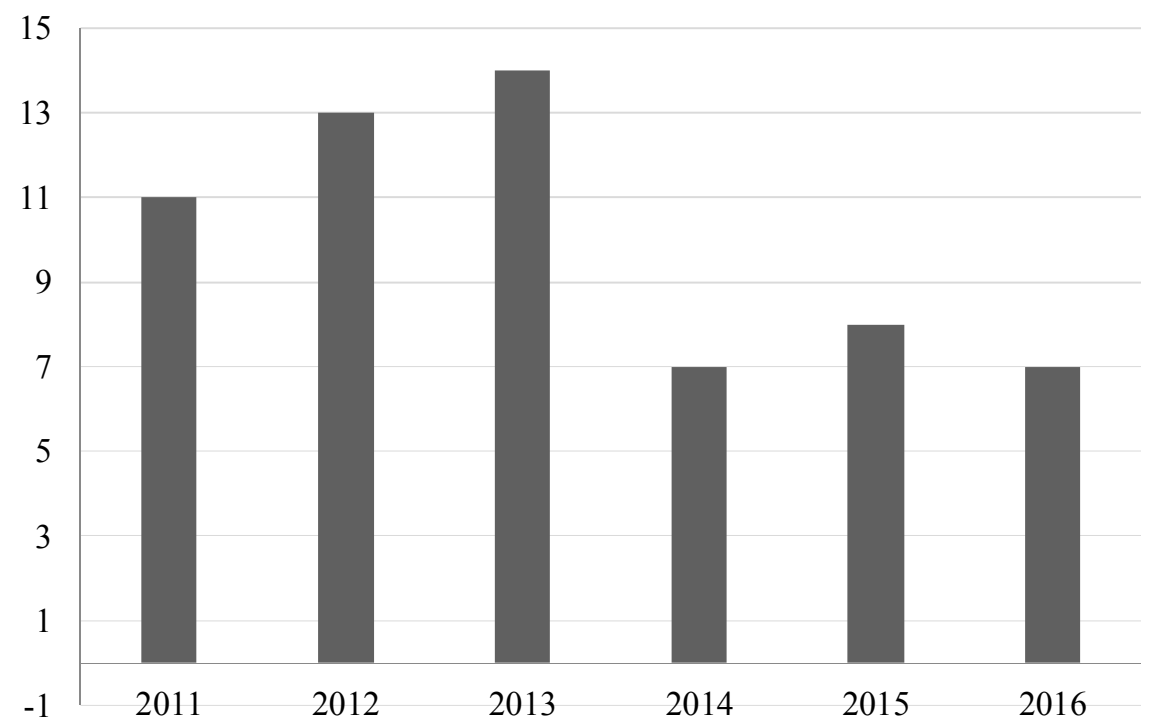

*Szacunek salda strukturalnego - zgodnie z wiosennymi prognozami Komisji z 2016 r. Wykres nie uwzględnia Wielkiej Brytanii, która jest zwolniona z wyznaczania MTO. Rok 2016, prognoza.

Źródło: AMECO. 
Wykres 12. Odsetek lat, w których saldo strukturalne w krajach członkowskich UE15 było zgodne $\mathrm{z}$ poziomem ich MTO lub których saldo strukturalne rosło w tempie $0,25 \mathrm{p}$. proc przy zadłużeniu $>=60 \%$ PKB lub było na stałym poziomie przy zadłużeniu $>60 \%$ PKB (lata 2010-2016)*

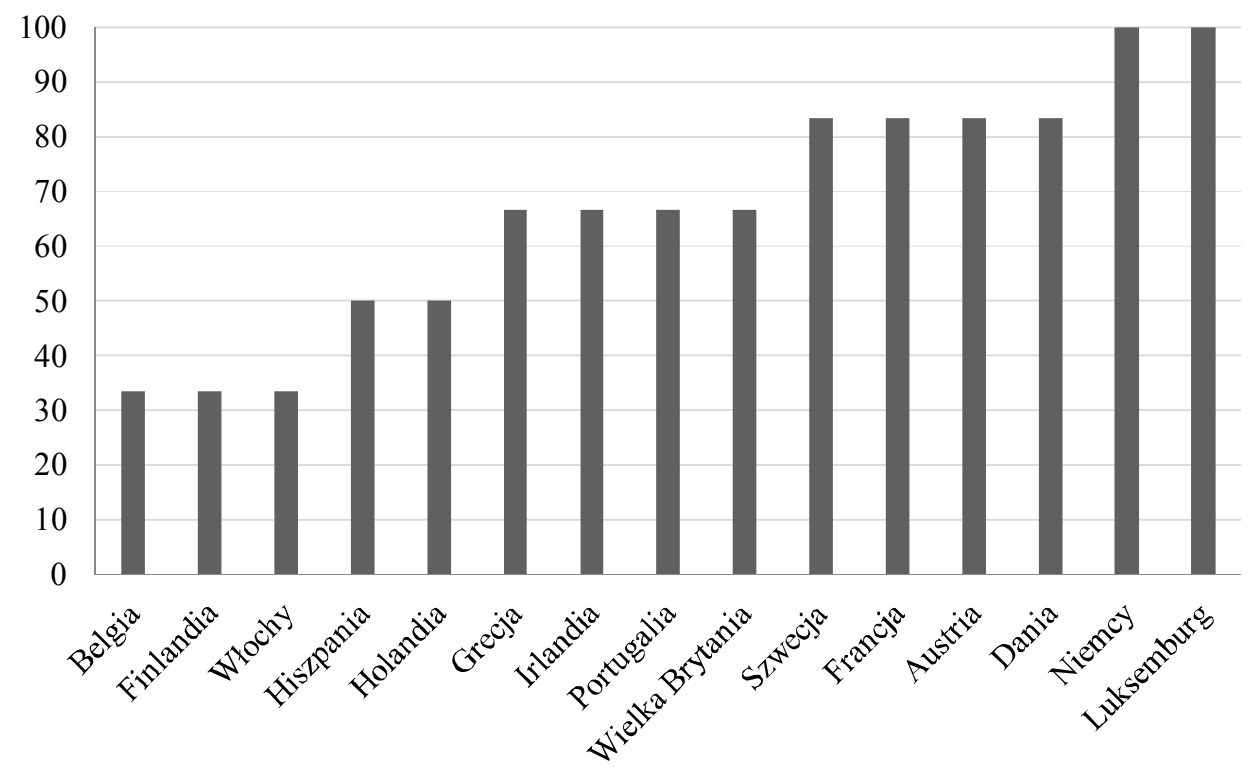

*Szacunek salda strukturalnego - zgodnie z wiosennymi prognozami Komisji z 2016 r. Wykres nie uwzględnia Wielkiej Brytanii, która jest zwolniona z wyznaczania MTO. Rok 2016, prognoza.

Źródło: AMECO.

Warto w tym kontekście spojrzeć jeszcze na dynamikę średniego salda strukturalnego analizowanych krajów. Zgodnie z wykresem 1 deficyt strukturalny w stosunku do PKB malał w latach 2005-2006. Spadek ten może być związany z tym, że w 2005 r. wprowadzono w ramach paktu stabilności i wzrostu regułę fiskalną opartą na poziomie salda strukturalnego. Deficyt malał także po kryzysie, od 2010 r., jednak dynamika tego spadku znacznie zmniejszyła się w ostatnich latach. Można więc stwierdzić, że chociaż kraje znacznie zmniejszały swoje deficyty strukturalne, począwszy od 2010 r., to jednak nie w takim stopniu, aby doprowadziło to do:

1) osiągnięcia MTO lub

2) utrzymania (po 2013 r.) tempa zmian salda strukturalnego na ścieżce dostosowawczej prowadzącej do MTO.

Warto dodać, że zgodnie z prognozami Komisji w 2016 r. jedynie w trzech krajach będących sygnatariuszami paktu fiskalnego poziom salda strukturalnego osiągnie poziom zgodny ze zobowiązaniem wynikającym z podpisania paktu - na poziomie równym co najmniej $-0,5 \%$ PKB (są to Grecja, Dania i Niemcy).

Jednocześnie średni poziom deficytu strukturalnego w analizowanych krajach od roku 2014 utrzymuje się na poziomie najniższym od 2002 r. Świadczy to o większym utrzymywaniu dyscypliny fiskalnej po 2014 r. niż w latach 2002-2013. 
Wykres 13. Średnie saldo strukturalne/PKB dla UE $15^{*}$ w latach 1999-2018

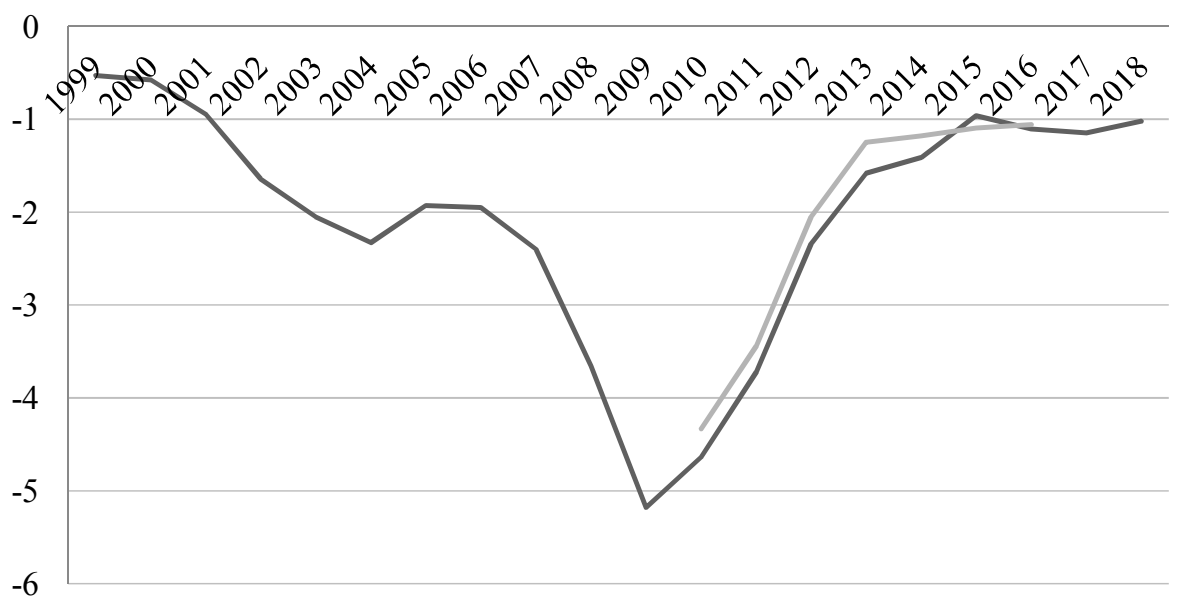

— baza World Economic Outlook, październik 2016 r.

baza AMECO, maj 2016 r.

* Lata 2016-2018, prognoza.

Źródło: AMECO, World Economic Outlook Database (wersja z października 2016 r.).

Ostatnie z kryteriów, którymi posługuje się Komisja, to kryterium tempa wzrostu wydatków. Zostało ono wprowadzone przez „sześciopak”, aby wesprzeć ocenę poziomu i zmian salda strukturalnego9. W praktyce ocenie tempa zmiany wydatków budżetowych podlegają kraje, których saldo strukturalne jest na poziomie MTO (ale nie powyżej MTO) lub które nie osiągnęły MTO i są na tzw. „ścieżce dostosowawczej” do jego osiągnięcia.

Analiza kryterium pozwala na lepsze przyjrzenie się przyczynom spadku korekty salda strukturalnego $\mathrm{w}$ analizowanych krajach po $2013 \mathrm{r}$.

Należy na wstępie podkreślić, że osiągnięcie takiego poziomu wydatków, który zapewnia odpowiedni poziom salda strukturalnego, może być jednak w praktyce utrudnione, ze względu na to, że:

1) Punktem odniesienia dla tempa wzrostu wydatków budżetowych jest średnioterminowy wzrost potencjalnego PKB, liczony jako średnia oszacowanego wzrostu potencjalnego PKB z 5 lat ubiegłych i prognozowanych na rok bieżący i 4 kolejne lata. Teoretycznie metodologia Komisji dotycząca prognozowania wzrostu potencjalnego PKB jest znana, jednak kraje członkowskie mają trudność z szacowaniem wielkości wzrostu potencjalnego PKB na lata $n+3$ i n+4, czyli wykraczające poza prognozy Komisji.

\footnotetext{
${ }^{9}$ Uzupełnienie miało być pomocne ze względu na: trudności z szacowaniem wysokości salda strukturalnego i lepszą kontrolę wydatków, których wzrost jest głównym powodem niespełniania kryteriów nakładanych przez reguły fiskalne.
} 
2) Szacunki wzrostu średnioterminowego potencjalnego PKB często się zmieniają, tak jak zmieniają się szacunki dotyczące wysokości salda strukturalnego.

Uwzględniając powyższe punkty, a także to, że ocena Komisji opiera się na tzw. agregacie wydatkowym, a nie na sumie wydatków ${ }^{10}$, warto jednak przyjąć pewne uproszczenia i przyjrzeć się dynamice wydatków w stosunku do potencjalnego PKB. W przypadku krajów, które osiągnęły swoje MTO, relacja wydatków rządowych do potencjalnego PKB powinna być stała w czasie, o ile wzrostowi nie towarzyszą odpowiednie zmiany po stronie przychodów. W przypadku krajów będących na „ścieżce dostosowawczej” prowadzącej do osiągnięcia MTO, relacja ta powinna maleć (również, o ile wzrostowi nie towarzyszą odpowiednie dostosowania po stronie przychodów) (Komisja Europejska 2016, s. 24).

Wykres 14 pokazuje, jak zmieniał się odsetek krajów UE 15, które spełniały warunek dotyczący tego, że wzrost wydatków budżetowych w stosunku do potencjalnego PKB jest mniejszy (lub równy) niż wzrost przychodów budżetowych w stosunku do potencjalnego PKB, włączając w to kraje, których saldo strukturalne przekroczyło poziom $\mathrm{MTO}^{11}$. Warunku nie spełniały ponadto kraje, w których spadek udziału wydatków w potencjalnym PKB był mniejszy niż spadek udziału przychodów. Na wykresie widać, że po 2011 r. zwiększyła się liczba krajów, w których zmiany wydatków w stosunku do potencjalnego PKB, wzrosty lub spadki, nie były większe niż zmiany (odpowiednio: wzrosty lub spadki) przychodów. Mogło na to wpłynąć wprowadzenie kryterium wydatkowego do paktu stabilności i wzrostu. Jednocześnie od 2014 r. maleją przychody w stosunku do potencjalnego PKB (patrz wykres 15). Zgodnie z prognozami Komisji przeciętny poziom wydatków w stosunku do potencjalnego PKB spadnie w 2018 r. do poziomu z 2002 r., a przychody będą wyższe niż w 2002 r. Mimo że poziom wydatków w stosunku do poziomu potencjalnego PKB nadal jest wyższy niż przed kryzysem, to wyższy jest także poziom przychodów w stosunku do potencjalnego PKB i różnica między poziomem wydatków a poziomem przychodów - wyrażonych w stosunku do potencjalnego do PKB - jest mniejsza. Wskazuje to na bardziej restrykcyjną politykę fiskalną niż przez $2014 \mathrm{r}$.

\footnotetext{
${ }^{10}$ Agregat wydatków obliczany jest jako wydatki rządowe pomniejszone o wydatki odsetkowe, wydatki związane z programami unijnymi, które są zwracane ze środków UE, i cykliczne elementy wydatków na bezrobocie (Komisja Europejska 2016, s. 49).

${ }^{11}$ Kraje, których saldo strukturalne osiągnęło poziom MTO, nie muszą spełniać kryterium przychodów. Nie uwzględniono tego warunku ze względu na brak pełnych danych z okresu 2002-2010 dotyczących spełniania przez salda strukturalne krajów poziomu MTO. Ponadto trzeba zaznaczyć, że wykres $15 \mathrm{w}$ przybliżeniu pokazuje skalę spełniania przez kraje UE 15 kryterium przychodów. W swojej ocenie Komisja analizuje bowiem zmiany całkowitej sumy wydatków skorygowane o płatności odsetek, wydatki na programy unijne i wydatki cykliczne związane $\mathrm{z}$ bezrobociem, a wydatki inwestycyjne zostają wygładzone (patrz Komisja Europejska 2016, s. 23). Ponadto w przypadku krajów, których saldo strukturalne jest poniżej MTO, wzrostu wydatków nie porównuje się ze wzrostem przychodów przy ocenie kryterium (jak to zostało zrobione w celu uzyskania danych przedstawionych na wykresie 15) - określana jest odpowiednia stopa wzrostu tych wydatków zapewniająca odpowiednie dostosowanie, aby saldo strukturalne osiągnęło MTO.
} 
Wykres 14. Liczba krajów z UE 15, w których wzrost/spadek wydatków budżetowych w stosunku do potencjalnego PKB jest mniejszy (ew. równy) niż wzrost/spadek przychodów budżetowych w stosunku do potencjalnego PKB (lata 2010-2016)*

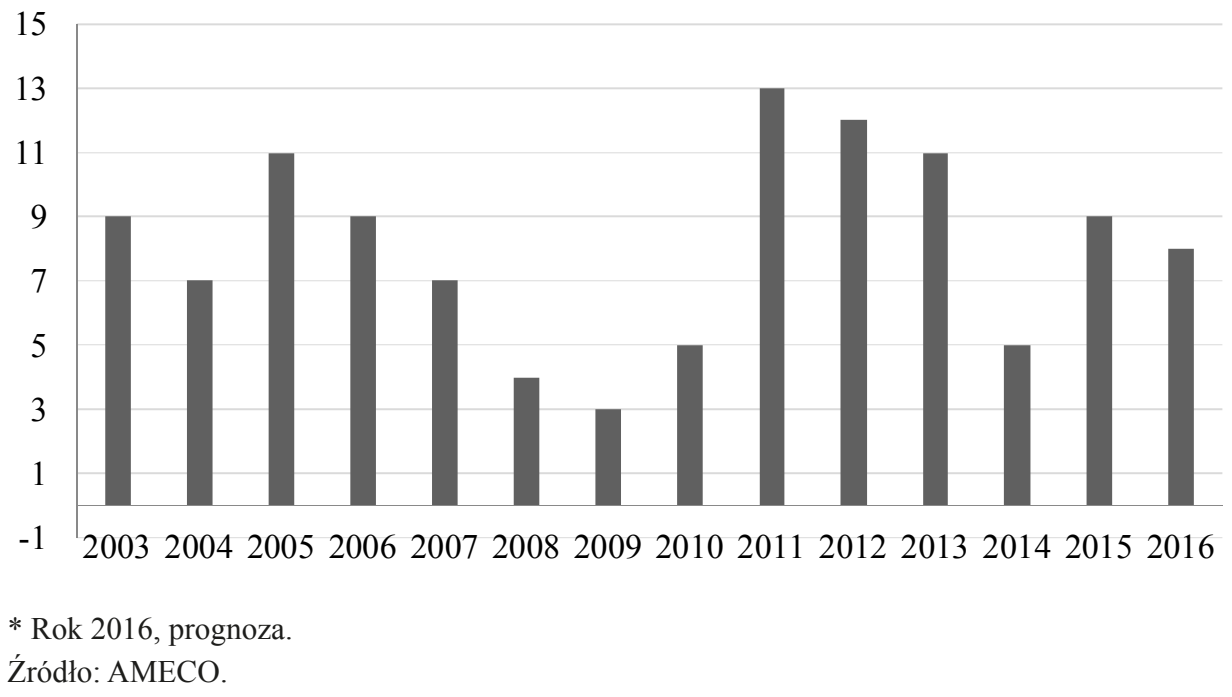

Wykres 15. Przeciętny poziom wydatków i przychodów budżetowych w stosunku do PKB potencjalnego w UE 15 (lata 2002-2018)*

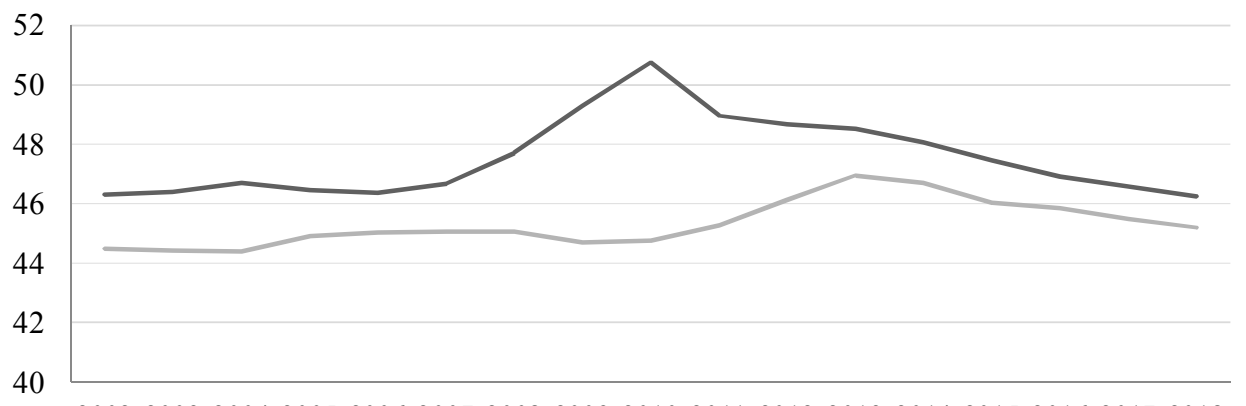

20022003200420052006200720082009201020112012201320142015201620172018

— poziom wydatków — poziom przychodów

* Lata 2016-2018, prognoza.

Źródło: AMECO.

\section{Podsumowanie}

Ocena stosowania się przez państwa członkowskie do reguł paktu w obecnym kształcie nie jest prosta, zwłaszcza w przypadku części prewencyjnej paktu. Wynika to z trudności związanych z szacowaniem salda strukturalnego i średnioter- 
minowego potencjalnego PKB, uwzględniających czynniki cykliczne. Wynika to także z elastyczności reguł, czyli uwzględniania w procesie oceniania wypełniania reguł przez dane państwo członkowskie specyficznych czynników umożliwiających odstępstwa od ich przestrzegania. Ewoluując, pakt stawał się coraz bardziej elastyczny, a reguły - coraz bardziej skomplikowane. Dlatego w ocenie przyjęto pewne uproszczenia. Artykuł nie jest zatem pełną analizą spełniania kryteriów, a raczej określonych w pakcie limitów dla poziomu deficytu budżetowego, długu publicznego, salda strukturalnego i wzrostu wydatków rządowych.

Ocena wypełniania reguł paktu prowadzi do wyodrębnienia dwóch głównych okresów: 1999-2007 (lata przedkryzysowe) i 2008-2016 (po rozpoczęciu kryzysu). W tych okresach można też wyodrębnić „podokresy”.

Większość analizowanych krajów UE 15 do 2007 r. przestrzegała limitów określonych przez reguły długu i deficytu. Co więcej, w latach 2005-2007 liczba krajów, które nie przestrzegały któregoś z tych kryteriów, zmalała. Po 2005 r. zmalał także zagregowany deficyt strukturalny analizowanej grupy krajów i zmniejszała się liczba krajów, w których zmianie poziomu wydatków budżetowych w stosunku do potencjalnego PKB nie towarzyszyła odpowiednia (równoważąca ją) zmiana przychodów. Jednocześnie wypełnianie limitów przez poszczególne kraje w latach 1999-2007 było zróżnicowane. Z wypełnianiem limitów deficytu budżetowego i długu publicznego - lub warunku „dostatecznego" zmniejszania długu w tym okresie - zdecydowanie najgorzej radziła sobie Grecja, która ani razu nie spełniła obu kryteriów. Ze spełnianiem kryterium deficytu - także Portugalia, a ze spełnianiem kryterium długu również Austria i Włochy. Kraje te nie podjęły wtedy wysiłków, aby w okresie sprzyjającej koniunktury zgromadzić nadwyżki, prowadziły procykliczną politykę fiskalną. Należy też zauważyć, że w latach 2005-2007 liczba krajów objętych procedurą nadmiernego deficytu jest bliższa liczbie krajów ocenionych w tym artykule jako niespełniające jednego z kryteriów niż w latach 2002-2004. Ogólnie rzecz biorąc, można stwierdzić, że po rozluźnieniu stosowania się do reguł paktu, które miało miejsce w latach 2002-2004, w okresie 2005-2007 nastąpiła pewna mobilizacja i zahamowanie owego rozluźnienia - do czasu wybuchu kryzysu.

W 2008 r. liczba krajów, które nie spełniły przynajmniej jednego z kryteriów drastycznie wzrosła - z 3 do 10 . W latach 2008-2015 przynajmniej 9 z 15 analizowanych krajów nie spełniło przynajmniej jednego kryterium. W latach 20092010 jedynie 4 kraje spełniały kryterium deficytu, a w latach 2010-2011 - długu. Poziom wydatków w stosunku do potencjalnego PKB rósł w analizowanych krajach do 2010 r. Począwszy od roku 2011, więcej krajów przestrzegło reguł paktu, zmniejszał się średni deficyt strukturalny oraz poziom wydatków w stosunku do potencjalnego PKB. Jednak liczba krajów przestrzegających reguł paktu jest nadal mniejsza niż przed kryzysem. Od 2014 r. przeciętny deficyt strukturalny maleje w coraz wolniejszym tempie, zaczęły też maleć przychody w stosunku do potencjalnego PKB. Jednocześnie coraz bardziej elastyczne zasady interpretacji 
paktu stabilności i wzrostu powodują, że procedurą nadmiernego deficytu objętych jest znacznie mniej krajów, niż wynika to wprost z przestrzegania limitów deficytu i długu. Można więc podsumować, że w latach 2009-2010 reguły nie były prawie w ogóle przestrzegane (kraje prowadziły antycykliczną politykę fiskalną), po czym w latach 2011-2013 nastąpiła większa mobilizacja fiskalna, co było działaniem procyklicznym, a następnie w latach 2014-2016 poziom spełniania kryteriów jeszcze wzrósł, ale nastąpiło rozluźnienie w podejściu Komisji do interpretacji reguł (większa elastyczność), aby umożliwić bardziej antycykliczne podejście w polityce fiskalnej.

Warto na koniec odnieść się do pytania postawionego w artykule: czy występowanie zjawiska deficit bias $\mathrm{w}$ analizowanych krajach UE wynika ze słabości reguł paktu stabilności i wzrostu czy też z nieprzestrzegania reguł przez kraje członkowskie? Mimo że sankcje - dopuszczalne przez pakt, aby zapewnić większą dyscyplinę budżetową - nie zostały ani razu uruchomione, na podstawie analizy przeprowadzonej $\mathrm{w}$ artykule można stwierdzić, że w analizowanym okresie nieskuteczność reguł w eliminowaniu zjawiska deficit bias wynika w dużej mierze z błędów konstrukcyjnych samych reguł. Zresztą błędy te mogą leżeć u źródła nieprzestrzegania reguł paktu. Zasadne wydaje się stwierdzenie, że jeśli kraje nie wierzą, że reguły zapewniają najlepszą dla nich politykę fiskalną - także w czasie recesji - to słusznie odrzucą ich stosowanie (patrz Claeys, Darvas 2016). W latach 2002-2007 większość państw przestrzegała reguł, a i tak nie zgromadzono wystarczających nadwyżek budżetowych na czasy gorszej koniunktury gospodarczej. Z kolei lata pokryzysowe pokazały, że reguły nie dość elastycznie zareagowały na warunki cykliczne i że konieczna jest ich reforma. Obecnie jedynie trzy kraje podlegają procedurze nadmiernego deficytu, a poziomy sald strukturalnych są dość wysokie (niskie deficyty strukturalne). Mimo to można powiedzieć, że skuteczność reguł fiskalnych UE w walce ze zjawiskiem deficit bias jest ograniczona. Jedną ze słabości reguł fiskalnych pozostaje bowiem to, że przekraczanie określonych wartości wskaźników nie jest wymagane w czasie przyspieszenia gospodarczego - określone są jedynie „,dolne limity” wskaźników. Dodatkowo większa elastyczność reguł sprawia, że kraje podlegają licznym wyłączeniom, które mogą pozostawiać pewien margines interpretacji w zakresie zgodności z zasadami paktu i czynią ją mniej zrozumiałą. W konsekwencji trudniej jest stwierdzić, czy dany kraj przestrzega reguł czy nie. Ponadto można mieć także wątpliwości co do wiarygodności oszacowanych wielkości sald strukturalnych poszczególnych państw.

Te wątpliwości pokazują, że reguły fiskalne nie są najlepszym środkiem do walki ze zjawiskiem deficit bias. Być może więcej do powiedzenia w kwestii unijnej polityki fiskalnej powinna mieć utworzona na mocy decyzji Komisji z 15 października 2015 r. Europejska Rada Fiskalna. 


\section{Bibliografia}

AMECO, Komisja Europejska, http://ec.europa.eu/economy_finance/ameco.

Calmfors L. (2014), The Roles of Fiscal rules, Fiscal Councils and Fiscal Union in EU integration, Uniwersytet Sztokholmski (Institute for International Economic Studies), Stockholm.

Claeys G., Darvas Z. (2016), How to reform EU fiscal rules, http://bruegel. org/2016/04/how-to-reform-eu-fiscal-rules (data dostępu: 12 kwietnia 2017 r.).

Darvas Z. (2016), The structural budget balance limbo, http://bruegel.org/2016/04/ the-structural-budget-balance-limbo (data dostępu: 12 kwietnia 2017 r.).

Eurostat, Komisja Europejska, http://ec.europa.eu/eurostat/data/database.

Komisja Europejska (2010), Report on the public finances in the EMU - 2010, Brussels.

Komisja Europejska (2011), Report on the public finances in the EMU - 2011, Brussels.

Komisja Europejska (2013), Report on the public finances in the EMU - 2013, Brussels.

Komisja Europejska (2014), Report on the public finances in the EMU - 2014, Brussels.

Komisja Europejska (2016), Vade Mecum on the Stability and Growth Pact, Brussels.

Mourre G., Astarita C., Princen S. (2014), Adjusting the budget balance for the business cycle: the EU methodology, European Commission Economic Papers 536, Brussels.

Parlament Europejski (2016), Potential output estimates and their role in the EU fiscal policy surveillance.

Rozporządzenie Rady nr 1466/97 z dnia 7 lipca 1997 r. w sprawie wzmocnienia nadzoru pozycji budżetowych oraz nadzoru i koordynacji polityk gospodarczych (Dziennik Urzędowy Unii Europejskiej, L 209).

Rozporządzenie Rady nr 1467/97 z dnia 7 lipca 1997 r. w sprawie przyspieszenia i wyjaśnienia procedury nadmiernego deficytu (Dziennik Urzędowy Unii Europejskiej, L 209).

Schaechter A., Kinda T., Budina N., Weber A. (2012), Fiscal Rules in Response to the Crisis - Toward the "Next-Generation" Rules. A New Dataset, IMF Working Paper, Washington DC.

Steinhouser G. (2016), Hawks Join Attack on EU Budget Rules, Wall Street Journal, 21.04.2016.

Traktat o funkcjonowaniu Unii Europejskiej - wersja skonsolidowana (Dziennik Urzędowy Unii Europejskiej, C 202).

Traktat o stabilności, koordynacji i zarządzaniu w unii gospodarczej i walutowej.

World Data Bank, Bank Światowy, http://databank.worldbank.org/data/home.aspx. 
World Economic Outlook Database, Międzynarodowy Fundusz Walutowy, wersja z października 2016 r., www.imf.org/external/pubs/ft/weo/2016/02/weodata/ index.aspx.

Wyplosz Ch. (2012), Fiscal rules: theoretical issues and historical experiences, National Bureau of Economic Research, Working Paper 17884, Cambridge, MA.

\section{Streszczenie}

Celem niniejszego artykułu jest przeanalizowanie stopnia przestrzegania przez 15 krajów UE reguł fiskalnych zawartych w pakcie stabilności i wzrostu w latach 1999-2015 i ewolucji tych reguł od początku ich sformułowania. Analiza stopnia wypełniania poszczególnych reguł prowadzi do wniosku, że na nieskuteczność reguł w eliminowaniu zjawiska deficit bias rzutują w dużej mierze ich błędy konstrukcyjne. W trakcie całego analizowanego okresu, a zwłaszcza okresu przedkryzysowego, można było stwierdzić, że limity określone przez reguły nie były przestrzegane, właściwie przez cały analizowany okres nie prowadziły do antycyklicznej polityki fiskalnej, a po kryzysie nie były wystarczająco elastyczne. Prowadzi to do konkluzji, że reguły fiskalne nie są najlepszym środkiem do walki ze zjawiskiem deficit bias w Unii Europejskiej.

Słowa kluczowe: reguły fiskalne, pakt stabilności i wzrostu, polityka fiskalna UE

\section{Summary}

\section{Deficit Bias and Effectiveness of the EU Fiscal Rules}

The aim of this article is to analyse the fulfilment of the Stability and Growth Pact rules by the EU 15 member states in the period 1999-2015. The article also presents the evolution of the EU fiscal rules since their formulation, including, in particular, the influence of the crisis on both meeting the rules by the member states and their substance. The conclusion of the article is that the construction of the rules is the main cause of the ineffectiveness of the pact in eliminating the deficit bias in the EU. In the analysed period, there were years when the member states did not follow the limits defined by the rules (the whole period, but in particular the years before the crisis), years without anticyclical influence of the rules (in fact, the whole period 1999-2015), and years when the rules turned out not to be elastic enough (the years after the crisis). It leads to the overall conclusion that the EU fiscal rules are not the best tool to counteract the deficit bias in the EU.

Keywords: fiscal rules, Stability and Growth Pact, fiscal policy in the EU

JEL: E62, H60, H87 